Int. J. Electrochem. Sci., 15 (2020) 9088 - 9107

\title{
Synergistic Effect of Zinc/aluminium-layered Double Hydroxide-clopyralid Carbon Nanotubes Paste Electrode in the Electrochemical Response of Dopamine, Acetaminophen, and Bisphenol A
}

Nurashikin Abd Azis ${ }^{1}$, Illyas Md Isa ${ }^{1,2, *}$, Norhayati Hashim ${ }^{1,2}$, Mohamad Syahrizal Ahmad ${ }^{1,2}$, Siti Nur Akmar Mohd Yazid ${ }^{1}$, Mohamad Idris Saidin ${ }^{1,2}$, Suyanta M.Si ${ }^{3}$, Rahadian Zainul ${ }^{4}$, Alizar Ulianas ${ }^{4}$, Mawardi Mawardi ${ }^{4}$, Siriboon Mukdasai ${ }^{5}$

${ }^{1}$ Department of Chemistry, Faculty of Science and Mathematics, Universiti Pendidikan Sultan Idris, 35900 Tanjong Malim, Perak, Malaysia

${ }^{2}$ Nanotechnology Research Centre, Faculty of Science and Mathematics, Universiti Pendidikan Sultan Idris, 35900 Tanjong Malim, Perak, Malaysia

${ }^{3}$ Department of Chemistry Education, Faculty of Mathematics and Natural Science, Yogyakarta State University, Yogyakarta, Indonesia

${ }^{4}$ Fakultas Matematika dan Ilmu Pengetahuan Alam, Universitas Negeri Padang, Kota Padang, Sumatera Barat, Indonesia

${ }^{5}$ Department of Chemistry, Faculty of Science, Khon Kaen University, Khon Kaen 40002, Thailand

*E-mail: illyas@ fsmt.upsi.edu.my

doi: $10.20964 / 2020.09 .04$

Received: 20 April 2020 / Accepted: 30 June 2020 / Published: 10 August 2020

A voltammetric sensor was developed using multiwalled carbon nanotubes (MWCNTs) paste electrode based zinc/aluminium-layered double hydroxide-clopyralid for simultaneous determination of dopamine (DA), acetaminophen (ACT), and bisphenol A (BPA). Several experimental conditions such as percent of modifier, $\mathrm{pH}$ of the solution, and square wave voltammetry parameters were optimized. The effective surface area of the electrodes was determined by chronocoulometry studies. The sensor demonstrated a linear plot of $7.0 \times 10^{-6}-5.0 \times 10^{-4} \mathrm{M}$ for DA, $3.0 \times 10^{-5}-5.0 \times 10^{-4} \mathrm{M}$ for ACT, and $3.0 \times 10^{-6}-5.0 \times 10^{-4} \mathrm{M}$ for BPA, with detection limit of $1.7 \times 10^{-7} \mathrm{M}, 1.8 \times 10^{-7} \mathrm{M}$, and $1.4 \times 10^{-7} \mathrm{M}$ respectively. The interferences from 10 to 40 -fold concentration of ascorbic acid, sodium salicylate, glucose, sucrose, glutamic acid, and captopril were negligible. The electrode also applicable for DA, $\mathrm{ACT}$, and BPA determination in urine, pharmaceutical tablets, and plastic products samples with recoveries between $92.3 \%$ and $109.7 \%$.

Keywords: Dopamine, Acetaminophen, Bisphenol A, Multiwalled carbon nanotubes, Square wave voltammetry, Nanocomposite 


\section{FULL TEXT}

(C) 2020 The Authors. Published by ESG (www.electrochemsci.org). This article is an open access article distributed under the terms and conditions of the Creative Commons Attribution license (http://creativecommons.org/licenses/by/4.0/). 